\title{
Assessing the susceptibility of the selected gourami (Osphronemus goramy) to Aeromonas hydrophila
}

\author{
RITA FEBRIANTI ${ }^{1,2, \vartheta}$, IKHSAN KHASANI ${ }^{2}$, KEUKEU KANIAWATI ROSADA $^{1, v v}$ \\ ${ }^{1}$ Department of Biology, Faculty of Mathematics and Natural Sciences, Universitas Padjadjaran. Jl. Raya Bandung-Sumedang Km. 21, Jatinangor, \\ Sumedang 45363, West Java, Indonesia. Tel./fax.: +62-22-7796412, `email: rita19002@mail.unpad.ac.id, “沓mail: keukeu@unpad.ac.id \\ ${ }^{2}$ Research Institute for Fish Breeding, Ministry of Marine and Fisheries. Jl. Raya 2 Sukamandi, Subang 41263, West Java, Indonesia
}

Manuscript received: 12 March 2021. Revision accepted: 26 May 2021.

\begin{abstract}
Febrianti R, Khasani I, Rosada KK. 2021. Assessing the susceptibility of the selected gourami (Osphronemus goramy) to Aeromonas hydrophila. Nusantara Bioscience 13: 111-120. A breeding program to improve the growth performance of the gourami fish was carried out through selection methods that produced faster growth gourami (selected population). The purpose of this study was to determine the susceptibility of the selected gourami to Aeromonas hydrophila infection based on tolerance limits (LD50) and investigated clinical signs post-injection of the pathogenic bacteria. The challenge test by intramuscular injection of $A$. hydrophila was done to the fingerling fish (15-20 g) for 14 days post-infection. The population of the tested fish was obtained from six families, selected gourami (SP), and non-selected control (CP) groups. Phosphate buffered saline (PBS) as control and several doses of the pathogen, $10^{2}$, $10^{4}, 10^{5}, 10^{6}, 10^{7}$, and $10^{8} \mathrm{CFU} / \mathrm{mL}$ of $A$. hydrophila, were injected into the fish. Fish mortality and clinical signs were observed daily. The fish mortality was confirmed by isolating bacteria in the fish which showed clinical signs, followed by biochemical characterization of the isolated bacteria using API 20E and PCR. The $\mathrm{LD}_{50}$ of $A$. hydrophila to the selected population $\left(9.70 \times 10^{5} \mathrm{CFU} / \mathrm{mL}\right)$ was higher than that of the control $\left(6.50 \times 10^{4} \mathrm{CFU} / \mathrm{mL}\right)$. On the final day of the test, the accumulation mortality of $\mathrm{CP}(63.33 \pm 5.77 \%)$ higher than that in SP $(33.33 \pm 5.77 \%)$. Based on the output test statistics, it was known that there was a significant difference between the mortality and clinical signs of SP and CP. The data suggested that the selected gourami were more resistant to A. hydrophila infection than that of the control. The A. hydrophila infection caused most of the major clinical signs, including mass mortality of the fish. The biochemical and PCR test ensure that fish mortality was caused by A. hydrophila infection.
\end{abstract}

Keywords: Aeromonas hydrophila, challenge test, clinical signs, fish breeding, selected gourami

\section{INTRODUCTION}

Giant gourami (Osphronemus goramy Lacepede 1801) is an Indonesian native fish with high economic value. The national productivity of the gourami consistently increased, from $35.09 \%$ in 2015 to $198.97 \%$ in 2017 , and $133.48 \%$ in 2018 (Ministry of Marine Affairs and Fisheries 2018). Therefore, the intensive farming of the fish has a high prospect to be developed. However, the slow growth character of the gourami is a serious problem to develop industrial farming of the fish. Disease attack is one of the obstacles in fish farming. Diseases can be caused by bacteria, viruses, parasites, and fungi. Bacterial disease in fish had been known since 1980. Aeromonas hydrophila bacteria causes Motile Aeromonad Septicemia (MAS) disease in gourami (Öztürk and Altinok 2014; Kusdarwati et al. 2018). Aeromonas hydrophila bacterial infection causes death and reduces the quality of the harvested fish (Purwaningsih et al. 2014). MAS disease is reported to cause mass mortality of cultured gourami in Indonesia. In 2016, the disease caused the loss of 47 tons of the gourami in West Sumatra (Department of Marine Affairs and Fisheries, Padang Pariaman Regency 2015), and mortality of $87-100 \%$ of the gourami population in the Banyumas area, the district of Central Java (Khumaidi and Hidayat 2018).

Intensive fish farming has a high prospect to be developed. Even though, the prevalence of disease outbreaks is relatively higher in this system. One of the major diseases in freshwater fish farming is Motile Aeromonad Septicemia (MAS) causing by A. hydrophila. The pathogenic bacteria cause tissue damage (invasiveness) and produce toxins (toxigenic) (Fernandez and Figueras 2020). The attack of $A$. hydrophila bacteria causes several clinical signs. Clinical signs are indications of the presence of a disease in the form of disease characteristics. According to Rozi et al (2018), the clinical signs of $A$. hydrophila bacteria attack is the presence of septicemic hemorrhage which is characterized by wounds on the body's surface, gills, ulcers, abscesses, exophthalmia, and flatulence. A. hydrophila bacteria cause disease outbreaks in catfish (Clarias sp.) (Kusdarwanti et al. 2017), tilapia (Oreochromis niloticus) (Hardi et al. 2018), gourami (Osphronemus goramy) (Rozi et al. 2018), and snakehead fish (Ophicephalus striatus) (Rao and Benarjee 2016). The determination of the observation period is based on the statement of Kusumawaty et al. (2016), that A.hydrophila bacterial infection in gourami is acute.

In the context of prevention and control of MAS disease, several strategies alternative has been done, including the management of integrated fish health, the use of MAS-free fish, and the vaccination (Ma et al. 2019). On the other hand, the specific pathogen resistance (SPR) of several cultured fishes has been developed in the world. Nevertheless, the SPR of MAS disease is not yet be 
reported. Based on our observation in the gourami population, there were wide variations in the resistance level of the fish to bacterial disease. Refer to Hendry et al. (2011), the high variation of a specific character (disease resistance) in the population suggested that a selection method may be conducted to improve the character. In the natural disease outbreak, there were 10-20\% of fish survive (survivor) (Subhan et al. 2020). Furthermore, the survivor can establish a based population to develop the SPR population (Moss et al. 2012). Based on the previous studies in the cultured species, selective breeding to produce MAS-resistant gourami may be conducted. Selective breeding for increased disease resistance is a promising strategy that has not been widely used in aquaculture. At the same time, improving growth performance is critical for efficient production (Hua et al. 2019). A study about the susceptibility of selected gourami, the specific strain of Indonesia, to A. hydrophila is not yet be conducted.

The breeding program to improve the growth character of the gourami has been conducted in Indonesia for several years. The breeding program was done through selection, hybridization, and genetic engineering (Nugroho et al. 2012; Sularto et al. 2016; Arifin et al. 2017). The main purpose of selection is to change the quantitative phenotype of the population mean by exploiting genetic additives that have a beneficial trait from elders to tillers. For this purpose, the base population with high genetic variation is important to produce superior varieties. Several years of breeding programs to improve the growth character of gourami had been conducted and resulted in a selected population. Besides growth, resistance to disease and tolerance to pond conditions are important factors to aquaculture productivity (Reid et al. 2019). Therefore, a study to evaluate the susceptibility level to the disease on the selected gourami was conducted. $\mathrm{LD}_{50}$ is the amount of a toxic agent (such as a poison, virus, or radiation) that is sufficient to kill 50 percent of a population of animals. The purpose of the recent study was to evaluate the resistance level of the selected gourami, based on tolerance limits $\left(\mathrm{LD}_{50}\right)$ and investigated clinical signs post-injection of the pathogenic bacteria.

\section{MATERIALS AND METHODS}

\section{Experimental location}

This research was conducted in February 2020 at the research facilities of the Research Institute for Fish Breeding, West Java, Indonesia, including the gourami hatchery, The Microbiology Laboratory, The Genetics Laboratory, and The Water Quality Laboratory. The Research Institute is located at latitude $6^{\circ} 22$ '20.6"S $107^{\circ} 37^{\prime} 18.5^{\prime \prime} \mathrm{E}$, and an altitude of 25 meters above sea level (GPS Coordinates 2017).

\section{Procedures}

Research design

A total of 420 fingerlings were used for both the selected gourami (SP) and non-selected control (CP) groups. The SP and CP groups were chosen because the SP group was the result of the selection that had faster growth than the CP group. In addition, disease resistance is a promising strategy that has not been widely used in cultivation. The healthy gourami fingerlings weighed $16.2 \pm 2.12 \mathrm{~g}$ of body weight and measured standard length $9.80 \pm 0.48 \mathrm{~cm}$. A completely randomized design was used in this study with seven treatments and three replicates. The treatments were infection of $A$. hydrophila to the gourami in several doses:

(i) SPP: Selected gourami injected with Phosphate Buffered Saline (PBS)

(ii) SP-10²: Selected gourami infected with $10^{2} \mathrm{CFU} / \mathrm{mL}$ of $A$. hydrophila

(iii) SP-10 ${ }^{4}$ : Selected gourami infected with $10^{4} \mathrm{CFU} / \mathrm{mL}$ of $A$. hydrophila

(iv) SP-10 5 : Selected gourami infected with $10^{5} \mathrm{CFU} / \mathrm{mL}$ of A. hydrophila

(v) SP-106 : Selected gourami infected with $10^{6} \mathrm{CFU} / \mathrm{mL}$ of $A$. hydrophila

(vi) $\mathrm{SP}-10^{7}$ : Selected gourami infected with $10^{7} \mathrm{CFU} / \mathrm{mL}$ of A. hydrophila

(vii) SP-10 $0^{8}$ Selected gourami infected with $10^{8} \mathrm{CFU} / \mathrm{mL}$ of A. hydrophila

(viii) CPP: Control gourami injected with Phosphate Buffered Saline (PBS)

(ix) $\mathrm{CP}-10^{2}$ : Control gourami infected with $10^{2} \mathrm{CFU} / \mathrm{mL}$ of $A$. hydrophila

(x) CP-10 ${ }^{4}$ : Control gourami infected with $10^{4} \mathrm{CFU} / \mathrm{mL}$ of $A$. hydrophila

(xi) CP-10 $0^{5}$ : Control gourami infected with $10^{5} \mathrm{CFU} / \mathrm{mL}$ of $A$. hydrophila

(xii) CP-10 $0^{6}$ : Control gourami infected with $10^{6} \mathrm{CFU} / \mathrm{mL}$ of $A$. hydrophila

(xiii) $\mathrm{CP}-10^{7}$ : Control gourami infected with $10^{7} \mathrm{CFU} / \mathrm{mL}$ of $A$. hydrophila

(xiv) CP-10 $0^{8}$ : Control gourami infected with $10^{8} \mathrm{CFU} / \mathrm{mL}$ of A. hydrophila

\section{Fish and acclimatization}

The population of the tested fish was obtained from six families, each for SP and CP. All the families resulted from one spawning batch in the controlled spawning pond of the gourami in the Research Institute for Fish Breeding. The fish were healthy and were free from A. hydrophila. Before the experimental tests, the fish were acclimatized for $14 \mathrm{~d}$ in fiber tanks (200 L capacity) under laboratory conditions. According to the research design, the normal fish, based on behavior, feeding response, and health status, were distributed in the $40 \mathrm{~L}$ of glass aquariums according to the research design.

Aeromonas hydrophila and preparation of the culture medium

Aeromonas hydrophila bacteria (American Type Culture Collection 35654 (ATCC 35654) was obtained from National Reference Laboratory the Biosafety in Microbiological and Biomedical Laboratories from the U.S. Department of Health and Human Services Centers for Disease Control and Prevention and National Institute for Health, belonging to the Collection of Bacterial 
Enteropathogens and maintained in cryopreservation. The liquid culture medium Tripton Soya Broth (TSB-Oxoid, England) was prepared according to the instructions of the manufacturer by dissolving $30 \mathrm{~g}$ in $1 \mathrm{~L}$ of distilled water. The sterilization was processed by autoclaving at $121^{\circ} \mathrm{C}$ for 15 min (Daihan Scientific Co., Ltd, Korea). The RS medium base (RS agar-Himedia, Mumbai) was prepared according to the manufacturer's instructions by dissolving $45.43 \mathrm{~g}$ in $990 \mathrm{~mL}$ of distilled water and it should not be sterilized using an autoclave. After removal and cooling between $45-50{ }^{\circ} \mathrm{C}$, one vial of Novobiocin Supplement (FD096) was added followed by homogenization and distribution to the sterile Petri plate.

\section{Preparation of A. hydrophila suspensions}

Bacterial suspensions were prepared by transferring a heave containing three to five colonies of A. hydrophila isolated in Petri dishes containing the RS agar medium after $24 \mathrm{~h}$ of cultivation at $31^{\circ} \mathrm{C}$ to tubes containing $10 \mathrm{~mL}$ of BHI broth and reincubated for $18 \mathrm{~h}$ in a bacteriological incubator (Memmert, Germany). After incubation of the bacterial suspensions with the culture, the logarithmic growth phase was measured by turbidity caused by bacterial growth; Spectrophotometer (Hitachi U1500, Japan) was designed to measure the optical density of a suspension of microorganisms. A bacterial growth test was carried out by growing a bacterial isolate from an agar slant, then inoculating one loop of $30 \mathrm{~mL}$ TSB medium and incubating it for $24 \mathrm{~h}$ at room temperature. Inoculation of the results of liquid culture on TSB media into new TSB media in a test tube of $2 \mathrm{~mL}$ of isolate on $8 \mathrm{~mL}$ of liquid TSB. Incubation at room temperature and measuring OD (optical density) with a spectrophotometer at a wavelength of $620 \mathrm{~nm}$ every two hours for $30 \mathrm{~h}$ (Zubaidah et al. 2019). Before being used as a pathogen test, A. hydrophila bacteria was restored through the test of Postulate Koch on SPF gourami varieties. The test of Postulate Kohn was carried out twice. Furthermore, this procedure was carried out by injecting $0.1 \mathrm{~mL}$ of inoculum into the test gourami intramuscularly (IM) (Taukhid et al. 2016).

\section{Susceptibility study of the gourami to A. hydrophila}

For the pathogenicity test, 420 gourami fishes were introduced into 42 research containers with $60 \mathrm{~L}$ water, and A. hydrophila was added intramuscularly injected of fish with PBS, $10^{2}, 10^{4}, 10^{5}, 10^{6}, 10^{7}$, and $10^{8} \mathrm{CFU} / \mathrm{mL}$. The mortality rate of the fish was recorded more than $24 \mathrm{~h}$ postinfection, and $\mathrm{LD}_{50}$ was determined. $\mathrm{LD}_{50}$ was estimated using the Dregsted Behrens method (Maryadi 2011). This study was carried out according to the principles adopted by the Brazilian College of Animal Experimentation (COBEA) and approved by the Committee on the Ethics of Animal Use (CEUA/UFAC: 08/2014).

\section{Clinical signs of the gourami after A. hydrophila infection}

The symptoms of infection were observed, and after 24$96 \mathrm{~h}$. The observations and measurements were carried out every $24 \mathrm{~h}$. The mortality rate of the fish was determined at the end of the study. Water quality parameters including temperature, $\mathrm{pH}$, dissolved oxygen, ammonia, nitrite, and nitrate were monitored at the beginning and end of the study. Observation of the clinical signs of gourami was carried out every 14 days (Taukhid et al. 2016).

\section{Confirmation test of the fish death}

The confirmation test aims to confirm the death of the gourami was caused by A. hydrophila bacteria. This test is performed by isolating bacteria from the liver, spleen, and kidneys, then purifying and characterizing it biochemically (API 20 E kit) and molecularly (PCR). The PCR method used is a method developed by (Alpha DNA Montreal, Quebec) using primary pairs of 16S F 5 'GGG AGT GCC TTC GGG AAT CAG A 3' and 16S R: 5'-TCA CCG CAA CAT TCT GAT TTG -3 ' with amplification of preheating temperature of $94^{\circ} \mathrm{C}$ for $2 \mathrm{~min}$, denaturation temperature of $94^{\circ} \mathrm{C}$ for $1 \mathrm{~min}$, the annealing temperature of $56^{\circ} \mathrm{C}$ for 30 sec, extension temperature of $72^{\circ} \mathrm{C}$ for $45 \mathrm{sec}$, final extension temperature of $72^{\circ} \mathrm{C}$ for 5 min with 30 cycles (Hussain et al. 2013). Furthermore, the PCR results were run by electrophoresis for $35 \mathrm{~min}$ with a voltage of $60 \mathrm{~V}$ and 400 A with a $1.5 \%$ agarose gel medium. The PCR product is seen in the High-Performance Ultraviolet Transilluminator with an amplicon target of approximately $356 \mathrm{bp}$. The data was processed with three replications of the measured data and analyzed descriptively.

\section{Data analysis}

Water quality data were reported as mean \pm SD. Observation of the clinical signs of the gourami was carried out every day by descriptive analysis to compare between groups. Water quality cultivation was used as a supporting parameter. Clinical signs were analyzed with a MannWhitney u test using SPSS. The data $\mathrm{LD}_{50}$ obtained from the research observation was analyzed using two-way ANOVA followed by Tukey's post hoc test to analyze data sets. The confirmation test was done to confirm the death of gourami is caused by A. hydrophila.

\section{RESULTS AND DISCUSSION}

\section{Susceptibility study of the gourami to $A$. hydrophila}

In aquaculture, disease outbreaks in aquaculture are affected by three factors, such as host, pathogen, and environment. This study evaluated several doses of the pathogenic bacteria (A. hydrophila) and two populations of the gourami in the optimal condition.

The susceptibility of SP to A. hydrophila was indicated by $100 \%$ mortality at a dose of $1 \times 10^{8} \mathrm{CFU} / \mathrm{mL}$ after $44 \mathrm{~h}$. Different $A$. hydrophila susceptibility seen in $\mathrm{CP}$ was indicated by $100 \%$ mortality at a dose of $1 \times 10^{8} \mathrm{CFU} / \mathrm{mL}$ and $1 \times 10^{7} \mathrm{CFU} / \mathrm{mL}$ after $24 \mathrm{~h}$. The A. hydrophila bacterial at a dose of $1 \times 10^{2} \mathrm{CFU} / \mathrm{mL}$ did not cause the death of the SP and CP. The $\mathrm{LD}_{50}$ value of $A$, hydrophila to the $\mathrm{CP}$, and SP were $6.50 \times 10^{4}$, and $9.70 \times 10^{5} \mathrm{CFU} / \mathrm{mL}$ respectively. The result of the analysis shows that $\mathrm{F}$ arithmetic is bigger than the $\mathrm{F}$ table (5\% and $1 \%$ ). Pairwise testing between SP and CP was performed by treatment when a significant interaction was found and multiple comparison adjustment was made using Tukey's 
method. There was a significant $(\mathrm{p}<0.05)$, with a calculated $\mathrm{F}$ value of $96.100>4.35 \mathrm{~F}$ table, it can be concluded that there were differences in mortality results based on the type of population and the concentration of infected bacteria. There was a significant $(p<0.05)$, with an $\mathrm{F}$ count of $146.650>2.87 \mathrm{~F}$ table, it can be concluded that there were differences in mortality results based on the type of gourami population. There was a significant ( $\mathrm{p}<$ $0.05)$, with an $F$ value of $14.350>2.87 \mathrm{~F}$ table, it can be concluded that there was an interaction based on the type of gourami population and the concentration of bacteria injected in determining mortality in gourami. This indicates that the A. hydrophila batch-test conducted for 14 days in gourami had a significant effect on the susceptibility of gourami. The mortality of the SP and CP during the $\mathrm{LD}_{50^{-}}$ 96h of A. hydrophila is presented in Table 1.

\section{Clinical signs of the gourami after $A$. hydrophila infection}

In addition to causing death in the test fish, bacterial infection with lower doses can cause physiological disturbances which are indicated by several clinical symptoms, including loss of balance (LB), loss of appetite (LA), weakness (W), ulcers (U), necrosis (N), and hemorrhagic $(\mathrm{H})$. Based on the output test statistics, it was known that the Asymp. Sig. (2-tailed) $<0.05$ for parameters LB, LA, W, U, N, and H. Thus there was a significant difference between the clinical signs of SP and CP. CP clinical symptoms were severe than SP. The clinical signs of the SP and CP post A. hydrophila infection presented in Table 2.

The early clinical signs that arise in this study were loss of balance or buoyancy control, floating upside down, or 'sitting' on the tank floor (most fish are normally only slightly negatively buoyant and take little effort to maintain the position the water column). As the disease progresses, the following may be observed: change in coloration, cloudy skin (indicates excess mucous production due to an irritant bacterial. Several hours after A. hydrophila injection, several clinical signs were observed in the infected gourami presented in Figure 1.

The bioassay pathogenic test must be conducted at the optimum level of water quality parameters to certain that the pathogen causes fish mortality. Refer to (Republic of Indonesia 2017), the main water parameters of the treatment tanks during this study were maintained at the optimum level for the giant gourami. They were 28.1$29.0^{\circ} \mathrm{C}$ of temperature, $8.00-8.42 \mathrm{of} \mathrm{pH}, 5.9-8.5 \mathrm{mg} / \mathrm{L}$ of DO, 0.0020-0.0163 mg/L of ammonia, 0.0097-0.0540 mg/L of nitrite, and $0.0430-0.9634 \mathrm{mg} / \mathrm{L}$ of nitrate. Based on the optimum level of water quality, the A. hydrophila infection causes the mortality of the fish during the recent study. The water quality parameters during this study were presented in Table 3.

\section{Confirmation test of the fish death}

Confirmation of fish mortality is carried out to ensure death due to the bacterial injection. All SP and CP fish were isolated from the dead fish from the liver, kidney, and spleen organs. As many as $100 \%$ of all SP and CP fish were isolated from the dead fish from the organs of the test results from the fermentative test, catalase test, gram stain test, PCR test, and API 20 E test showed that A.hydrophila caused the death of gourami. The fermentative test showed the color of the media turned yellow (Figure 2.A-B). The catalase test on bacteria that caused clinical signs showed positive results due to the formation of bubbles (Figure 2.C-D). Pure isolated bacteria were then stained and the result was that the bacteria were rod-shaped, short-chain, and red when tested with gram stain (Figure 2.E). The results of the PCR and API $20 \mathrm{E}$ tests showed that fish mortality was caused by infection with A. hydrophila bacteria (Hussain et al. 2013). The results of confirmation bacterial isolation $A$. hydrophila of liver, kidney, and spleen organs of fish showed a band around $356 \mathrm{bp}$ presented in Figure 3. Tests using API 20 E showed very good identification results with a percent ID value of $99 \%$ presented in Table 4.

\section{Discussion}

The $\mathrm{LD}_{50}$ use of host death provides a nonequivocal endpoint and measurement has the advantage that it allows comparisons across microbes (Casadeval 2017). LD L0 $_{50}$ figures are frequently used as a general indicator of a substance's acute toxicity. A lower $\mathrm{LD}_{50}$ is indicative of increased toxicity (Aisiah et al. 2020). Growth and survival are the major character in the aquaculture system and most selection programs focused on these traits (Krishna et al. 2011; Gjedrem et al. 2012). Based on these data, the $\mathrm{LD}_{50}$ value of $A$. hydrophila to the control, and selected gourami were $6.50 \times 10^{4}$ and $9.70 \times 10^{5} \mathrm{CFU} / \mathrm{mL}$, respectively. At this time, the average mortality in the control gourami had reached $63.33 \pm 5.77 \%$ and was significantly higher ( $\mathrm{p}<$ $0.05)$ compared to that of selected gourami $(33.33 \pm 5.77 \%)$. After $96 \mathrm{~h}$ post-infection, the gourami in both the control and selected groups showed normal behavior.

Table 1. Mortality of the selected gourami (SP) and control (CP) during the $\mathrm{LD}_{50}-96 \mathrm{~h}$ of Aeromonas hydrophila

\begin{tabular}{|c|c|c|c|c|}
\hline $\begin{array}{c}\text { Pathogen } \\
\text { concentration } \\
(\mathrm{CFU} / \mathrm{mL}) \\
\end{array}$ & $\begin{array}{c}\text { Number } \\
\text { of fishes } \\
(\mathbf{0 ~ h}) \\
\end{array}$ & $\begin{array}{c}\begin{array}{c}\text { Number of } \\
\text { dead fishes } \\
(96 \mathrm{~h})\end{array} \\
\end{array}$ & $\begin{array}{c}\text { Mortality } \\
(\%)\end{array}$ & $\begin{array}{c}\text { LD50 } \\
\text { (CFU/mL) }\end{array}$ \\
\hline SPP & 30 & 0 & $0.00 \pm 0.00$ & $9.70 \times 10^{5}$ \\
\hline SP- $10^{2}$ & 30 & 0 & $0.00 \pm 0.00$ & \\
\hline SP- $10^{4}$ & 30 & 25 & $16.67 \pm 0.58$ & \\
\hline SP- $10^{5}$ & 30 & 23 & $23.33 \pm 5.77$ & \\
\hline SP- $10^{6}$ & 30 & 20 & $33.33 \pm 5.77$ & \\
\hline SP- $10^{7}$ & 30 & 14 & $53.33 \pm 5.77$ & \\
\hline SP- $10^{8}$ & 30 & 30 & $100.00 \pm 0.00$ & \\
\hline CPP & 30 & 30 & $0.00 \pm 0.00$ & $6.50 \times 10^{4}$ \\
\hline CP- $10^{2}$ & 30 & 1 & $3.33 \pm 5.77$ & \\
\hline CP- $10^{4}$ & 30 & 7 & $23.33 \pm 5.77$ & \\
\hline CP- $10^{5}$ & 30 & 13 & $43.33 \pm 5.77$ & \\
\hline CP- $10^{6}$ & 30 & 19 & $63.33 \pm 5.77$ & \\
\hline CP- $10^{7}$ & 30 & 30 & $100.00 \pm 0.00$ & \\
\hline $\mathrm{CP}-10^{8}$ & 30 & 30 & $100.00 \pm 0.00$ & \\
\hline
\end{tabular}


Pairwise testing between SP and CP was performed by treatment when a significant interaction was found and multiple comparison adjustment was made using Tukey's method. Based on the output test statistics, it was known that the significant $<0.05$ for mortality. Thus there was a significant difference between the mortality of SP and CP. The susceptibility of CP was higher than SP. On the final day of the test, the accumulation mortality of $\mathrm{CP}$ had reached $63.33 \pm 5.77 \%$, which was considerably higher than that in SP $(33.33 \pm 5.77 \%)$ (Tabel 1). Fish susceptibility is manifested in fish mortality. Based on Table 1, the highest mortality occurred at a bacterial dose of $10^{8} \mathrm{CFU} / \mathrm{mL}$ of $100 \%$. Determining of clinical signs was done by observing the wounds on the outside of the body and the behavior of the gourami seeds infected with A. hydrophila bacteria.
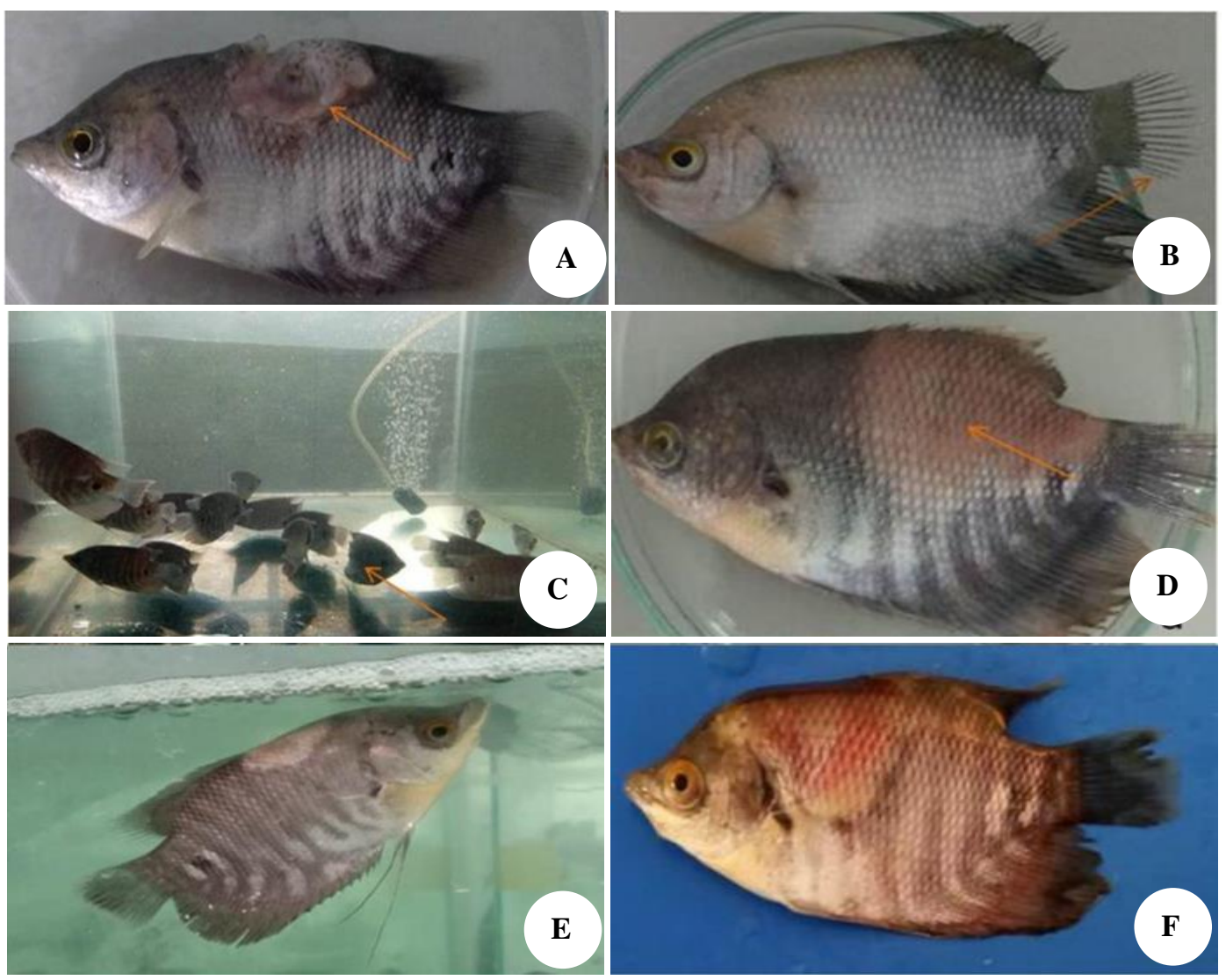

Figure 1. Clinical signs in the $O$. goramy were intramuscularly injected with Aeromonas hydrophila: A. Ulcers, B. Injury on caudal fin with hemorrhagic foci, C. Swimming at the bottom, D. Lesion at the site of A hydrophila inoculation, E. Weakness, and F. Integumentary injuries with depigmentation and hemorrhagic foci

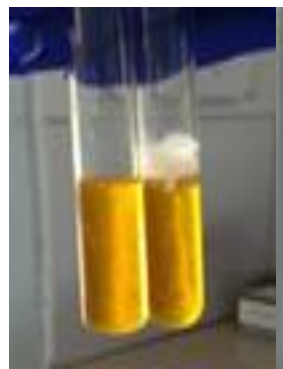

A

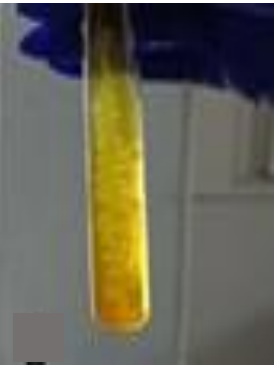

B

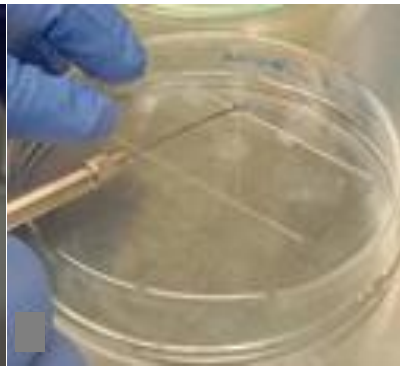

C

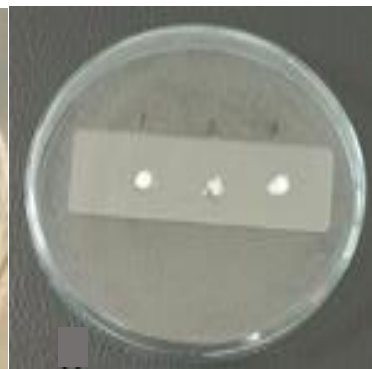

D

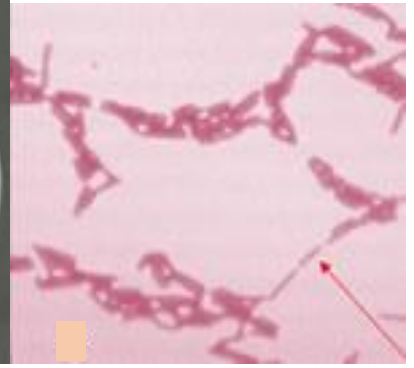

$\mathbf{E}$

Figure 2. Confirmation of clinical signs and fish mortality by detection of bacteria: A. OF test, B. Test fermentative (TSIA), C. KOH test, D. Catalase test, and E. Gram stain test 
Table 2. The clinical signs of the selected gourami (SP) and control (CP) post Aeromonas hydrophila infection

\begin{tabular}{|c|c|c|c|}
\hline \multirow{2}{*}{$\begin{array}{l}\text { Observation } \\
\text { time (hours) }\end{array}$} & \multicolumn{2}{|c|}{ Clinical signs } & \multirow{2}{*}{ Footnote } \\
\hline & SP & $\mathbf{C P}$ & \\
\hline 0 & LA-,W-,H-,N-, LB-, U- & LA-,W-,H-,N-, LB-, U- & LA: Loss appetite \\
\hline 12 & $\mathrm{LA}-, \mathrm{W}+, \mathrm{H}-, \mathrm{N}_{-}, \mathrm{LB}-, \mathrm{U}-$ & $\mathrm{LA}+, \mathrm{W}++, \mathrm{H}+, \mathrm{N}+, \mathrm{LB}+, \mathrm{U}+$ & W: Weakness \\
\hline 24 & $\mathrm{LA}+, \mathrm{W}+, \mathrm{H}_{-}, \mathrm{N}-, \mathrm{LB}+, \mathrm{U}+$ & $\mathrm{LA}++, \mathrm{W}++, \mathrm{H}++, \mathrm{N}++, \mathrm{LB}++, \mathrm{U}++$ & $\mathrm{H}$ : hemorrhagic \\
\hline 48 & $\mathrm{LA}+, \mathrm{W}+, \mathrm{H}+, \mathrm{N}+, \mathrm{LB}+, \mathrm{U}+$ & $\mathrm{LA}++, \mathrm{W}++, \mathrm{H}++, \mathrm{N}+++, \mathrm{LB}++, \mathrm{U}++$ & NF: Necrosis \\
\hline 72 & $\mathrm{LA}++, \mathrm{W}+, \mathrm{H}++, \mathrm{N}++, \mathrm{LB}+, \mathrm{U}++$ & $\mathrm{LA}++, \mathrm{W}++, \mathrm{H}+++, \mathrm{N}+++, \mathrm{LB}++, \mathrm{U}+++$ & LB: Loss of balance \\
\hline 96 & $\mathrm{LA}+, \mathrm{W}+, \mathrm{H}++, \mathrm{N}++, \mathrm{LB}+, \mathrm{U}++$ & $\mathrm{LA}+++, \mathrm{W}++, \mathrm{H}+++, \mathrm{N}+++, \mathrm{LB}+, \mathrm{U}+++$ & U: Ulcers \\
\hline 120 & $\mathrm{LA}+, \mathrm{W}++, \mathrm{H}+, \mathrm{N}+, \mathrm{LB}-, \mathrm{U}+$ & $\mathrm{LA}++, \mathrm{W}+++, \mathrm{H}+++, \mathrm{N}++, \mathrm{LB}+, \mathrm{U}++$ & -: no symptoms \\
\hline 144 & $\mathrm{LA}+, \mathrm{W}++, \mathrm{H}+, \mathrm{N}-, \mathrm{LB}-, \mathrm{U}+$ & $\mathrm{LA}++, \mathrm{W}+++, \mathrm{H}++, \mathrm{N}+, \mathrm{LB}+, \mathrm{U}++$ & + : low \\
\hline 168 & LA-, W-, H-, N-, LB-, U+ & $\mathrm{LA}++, \mathrm{W}+, \mathrm{H}+, \mathrm{N}+, \mathrm{LB}+, \mathrm{U}++$ & ++ : moderate \\
\hline 192 & LA-, W-, H-, N-, LB-, U- & LA-, W-, H-, N-, LB-, U- & +++ : severe \\
\hline 216 & LA-, W-, H-, N-, LB-, U- & LA-, W-, H-, N-, LB-, U- & \\
\hline 240 & LA-, W-, H-, N-, LB-, U- & LA-, W-, H-, N-, LB-, U- & \\
\hline 264 & LA-, W-, H-, N-, LB-, U- & LA-, W-, H-, N-, LB-, U- & \\
\hline 288 & LA-, W-, H-, N-, LB-, U- & LA-, W-, H-, N-, LB-, U- & \\
\hline 312 & LA-, W-, H-, N-, LB-, U- & LA-, W-, H-, N-, LB-, U- & \\
\hline 336 & LA-, W-, H-, N-, LB-, U- & LA-, W-, H-, N-, LB-, U- & \\
\hline
\end{tabular}

Table 3. Water quality conditions of the selected gourami (SP) and control (CP) during the LD50-96h of Aeromonas hydrophila

\begin{tabular}{ccccccc}
\hline $\begin{array}{c}\text { Patogen concentration } \\
(\mathbf{C F U} / \mathbf{m L})\end{array}$ & Temperature $\left({ }^{\circ} \mathbf{C}\right)$ & $\begin{array}{c}\text { DO } \\
(\mathbf{m g} / \mathbf{L})\end{array}$ & $\mathbf{p H}$ & $\begin{array}{c}\text { Ammonia } \\
(\mathbf{m g} / \mathbf{L})\end{array}$ & $\begin{array}{c}\text { Nitrite } \\
(\mathbf{m g} / \mathbf{L})\end{array}$ & $\begin{array}{c}\text { Nitrate } \\
(\mathbf{m g} / \mathbf{L})\end{array}$ \\
\cline { 2 - 7 } & $28.7-29.0$ & $8.2-8.5$ & $8.02-8.20$ & $0.0023-0.0132$ & $0.0385-0.0540$ & $0.0532-0.7850$ \\
SPP & $28.4-28.9$ & $7.4-7.7$ & $8.05-8.10$ & $0.0130-0.0123$ & $0.0110-0.0234$ & $0.0430-0.9634$ \\
SP-10 & $28.5-28.7$ & $6.9-7.0$ & $8.40-8.42$ & $0.0090-0.0130$ & $0.0097-0.0172$ & $0.0843-0.5870$ \\
SP-10 & $28.2-28.6$ & $6.0-7.1$ & $8.02-8.30$ & $0.0024-0.0130$ & $0.0122-0.0242$ & $0.0432-0.9630$ \\
SP-10 & $28.1-28.8$ & $6.1-6.4$ & $8.22-8.37$ & $0.0073-0.0090$ & $0.0154-0.0340$ & $0.3760-0.6260$ \\
SP-10 & $28.2-28.6$ & $6.0-6.3$ & $8.10-8.21$ & $0.0035-0.0086$ & $0.0145-0.0321$ & $0.1876-0.6589$ \\
SP-10 & $28.2-29.0$ & $5.9-6.3$ & $8.00-8.10$ & $0.0022-0.0163$ & $0.0148-0.0367$ & $0.1743-0.3398$ \\
SP-10 & $28.3-28.9$ & $8.1-8.4$ & $8.01-8.20$ & $0.0026-0.0142$ & $0.0388-0.0540$ & $0.0532-0.7856$ \\
CPP & $28.2-28.8$ & $7.3-7.6$ & $8.06-8.10$ & $0.0128-0.0143$ & $0.0114-0.0238$ & $0.0432-0.9484$ \\
CP-10 & $28.4-28.8$ & $6.8-7.1$ & $8.39-8.42$ & $0.0092-0.0132$ & $0.0104-0.0176$ & $0.0840-0.5670$ \\
CP-10 & $28.3-28.5$ & $6.1-7.2$ & $8.12-8.30$ & $0.0028-0.0130$ & $0.0126-0.0244$ & $0.0532-0.9632$ \\
CP-10 & $28.2-28.9$ & $6.2-6.4$ & $8.22-8.37$ & $0.0073-0.0090$ & $0.0154-0.0348$ & $0.3840-0.6266$ \\
CP-10 & $28.3-28.7$ & $6.1-6.3$ & $8.14-8.21$ & $0.0038-0.0088$ & $0.0148-0.0324$ & $0.1882-0.7658$ \\
CP-10 & $28.2-28.9$ & $5.9-6.2$ & $8.00-8.20$ & $0.0020-0.0163$ & $0.0152-0.0382$ & $0.1842-0.3698$ \\
CP-10 & & & & & & $\leq 20$ \\
Threshold value & $25.0-30.0$ & $>3.0$ & $6.50-8.50$ & $\leq 0.02$ & & \\
(Republic of Indonesia & & & & & & \\
2017) & & & & & & \\
\hline
\end{tabular}

Table 4. Identification of bacteria using the API 20 E kit

\begin{tabular}{|c|c|c|c|c|c|c|}
\hline \multirow{2}{*}{$\begin{array}{c}\text { Reference: Very good identification } \\
\text { Significant Taxa } \\
\end{array}$} & \multirow{2}{*}{$\%$ ID } & \multirow{2}{*}{$\mathbf{T}$} & \multirow{2}{*}{\multicolumn{4}{|c|}{ Test against }} \\
\hline & & & & & & \\
\hline Aeromonas hydrophila/caviae/sobria 2 & 99.0 & 1.0 & \multirow{2}{*}{\multicolumn{4}{|c|}{ Test against }} \\
\hline Next taxon & $\%$ ID & $\mathrm{T}$ & & & & \\
\hline Aeromonas hydrophila/caviae/sobria 1 & 99.0 & 0.69 & LDC $25 \%$ & CIT $25 \%$ & VP $25 \%$ & ARA $75 \%$ \\
\hline Complementary test(s) & \multicolumn{2}{|c|}{ Glucose g } & \multicolumn{2}{|c|}{ ESC (HYD) } & $0 / 129 \mathrm{R}$ & Methyl Red \\
\hline Aeromonas caviae & \multicolumn{2}{|c|}{-} & \multicolumn{2}{|c|}{+} & + & + \\
\hline Aeromonas hydrophila & \multicolumn{2}{|c|}{+} & \multicolumn{2}{|c|}{+} & + & $86 \%$ \\
\hline Vibrio fluvialis & \multicolumn{2}{|c|}{$0 \%$} & \multicolumn{2}{|c|}{ NT } & - & NT \\
\hline Aeromonas sobria & \multicolumn{2}{|c|}{+} & \multicolumn{2}{|c|}{ - } & + & - \\
\hline
\end{tabular}




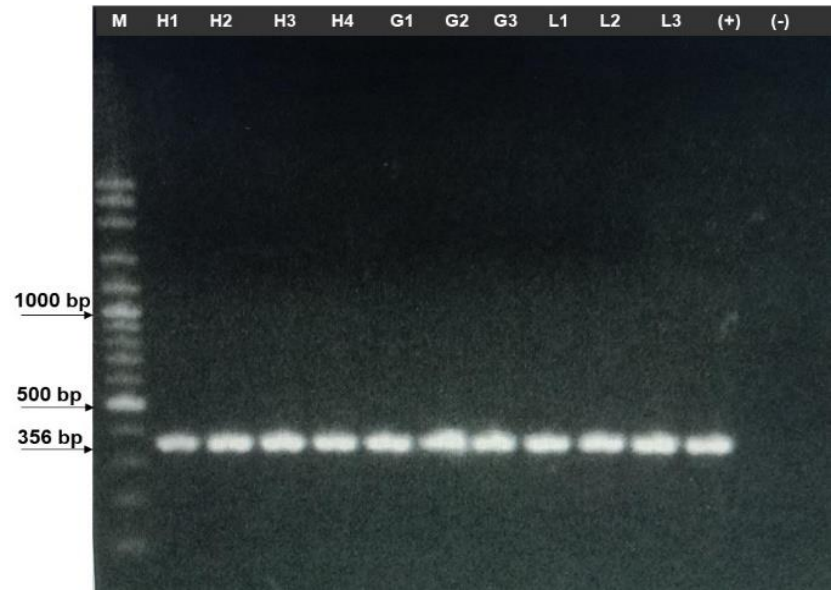

Figure 3. Gel electrophoresis of product using 16S F \& $16 \mathrm{~S}$ R primers, $\mathrm{M}$ denotes 100 bp DNA ladder (Marker), H1-H4: liver, G1-G3: kidney, L1-L3: spleen, (+): positive control, and (-): negative control

This study showed that the selected gourami was higher resistant than the control. Because, selected gourami had high genetic variation, it will provide a great opportunity to get the right combination of crosses with good disease resistance (Suprapto and Kairudin 2017). Selected gourami can be used as a candidate for superior gourami. According to Sularto et al. (2020), the growth of selected gourami in nursery and resistance phases was higher than that of the control. This corresponds to the results of the study of the $\mathrm{LD}_{50}$ value of selection gourami were higher than pure gourami (Sularto et al. 2020). High genetic variation will provide a great opportunity to get the right cross combination with a good combination of traits (Suprapto and Kairudin 2017). Based on the result, the selection program to increase resistance to gourami. On the other hand, Sularto et al. (2020) reported the SP groups had better growth than $\mathrm{CP}$. Based on the result, the selection program to increase resistance to gourami did not negatively affect the growth of gourami. Therefore, a breeding program to improve the resistance level of the gourami to specific pathogen could be applied in the giant gourami. Besides that, other selection lines based on the growth character of the gourami have improved $11,18 \%$ of their productivity (Sularto et al. 2020).

The correlation pattern between disease resistance and growth is host-specific and pathogen-specific (Gjedrem 2015). On the other hand, Suebsong et al. (2019) reported the same thing selective breeding programs have significant potential to make tilapia more resistant to Streptococcus agalactiae. Heritability estimates for G0 were 0.22 using the Cox model. At the same time, the researchers noted that selection response indicated that the risk of death decreased to 54 percent, survival time increased to 3.4 days. Survival rate increased to $21 \%$, suggesting that breeding tilapia that are more resistant to $S$. agalactiae is possible. On the other hand, faster growth also occurring in disease-resistant populations has been reported in several aquaculture species. Parker et al. (2011) reported that Line 1 grows at twice the rate of non-selected oysters, has a higher standard metabolic rate, and has a significantly higher survival when exposed to elevated levels of $\mathrm{PCO}_{2}$ and temperature predicted to occur as a result of climate change. Differences in reproductive status between fifth-generation fast growth oysters and nonselected oysters were found by Dove and O'Connor (2012). The authors are monitoring changes in reproductive condition in Lines 1-3 to determine if this also occurs in SROs bred for disease resistance. Huang et al. (2012) reported that that Pacific whiteleg shrimp having 21\% higher resistance to WSSV grew $34.51 \%$ faster than that of the control. Another study showed that the growth of oyster resistant (Crassostrea gigas) to herpesvirus 1 (OsHV-1) was $15 \%$ faster than that of the control (Lionel et al. 2015). Furthermore, Khasani et al. (2017) reported that the growth of giant freshwater prawns (Macrobrachium rosenbergii) resistant to vibriosis was $46 \%$ higher than that of the control. The neutral correlation between growth and resistance to bacterial cold-water disease was also observed in rainbow trout. Besides that, the growth of Atlantic salmon (Salmo salar) resistance to Piscirickettsia salmonis and Caligus rogercresseyi was similar to that of the normal fish (Yanez et al. 2014). Another case reported that genetic correlations between body weights and WSSV resistance in Pacific Whiteleg Shrimp and Liptopenaeus vannamei were negative (Trang et al. 2019).

The $\mathrm{LD}_{50}$ of $A$. hydrophila in this study is lower than in several previous studies. The $\mathrm{LD}_{50}$ of Bogor gourami was $10^{8} \mathrm{CFU} / \mathrm{mL}$ (Taukhid et al. 2016), tilapia was $4.9 \times 10^{6}$ CFU/mL (Mangunwardoyo et al. 2016), Arapaima gigas was $1.8 \times 10^{8} \mathrm{CFU} / \mathrm{mL}$ (Dias et al. 2016), strain K14 in African catfish was $4.977 \times 10^{5} \mathrm{CFU} / \mathrm{mL}$ (Wulandari et al. 2014), and strain ASB01 in snakehead was $2.69 \times 10^{5}$ CFU/mL (Olga 2014). Citterio and Biavasco (2015) classify A. hydrophila into virulent and non-virulent bacteria. A. hydrophila isolates with an $\mathrm{LD}_{50}$ of $10^{4.5}-10^{5.5}$ $\mathrm{CFU} / \mathrm{mL}$ were declared virulent, while A. hydrophila isolates with an $\mathrm{LD}_{50}$ of $10^{7} \mathrm{CFU} / \mathrm{mL}$ or more were declared non-virulent. The mortality in gourami infected with A. hydrophila proves that the bacteria are pathogenic and very virulent in fish. Characteristics of bacteria that are pathogens include transmissibility, adherence to host cells, persistence, invasion of host cells and tissues, toxigenicity, and the ability to evade or survive the host's immune system (Jawetz et al. 2014). This difference is probably due to differences in serotype and biotype of bacteria, fish species, and temperature (Olga 2014). Besides that, the difference in test results and $\mathrm{LD}_{50}$ calculations is thought to be due to the very different sources of origin of bacteria and host fish used (Makrinos and Bowden 2016; Li et al 2017; Yengkhom et al. 2019). Changes in the physical and chemical characteristics of the environment can increase the abundance and virulence of pathogenic organisms as can genetic mutation, factors which must have an important influence on the outcome of a situation in which pathogens challenge fish in the water (Tripathi et al. 2018). However, another influence, namely the degree of susceptibility of the host, may also be instrumental in determining whether or not pathogenic challenge results in disease (Tipathi et al. 
2018). Therefore, disease predisposition in fish can be said to be the end result of an interaction between host susceptibility, pathogen virulence, and environmental factors (stressors) (Gjedrem 2015). Stress weakens fish immune systems, and increases susceptibility to disease (Abram et al. 2017).

Further clinical signs are the appearance of white spots on the body of the fish, mucus accumulation on the body, skin lesions, white pectoral fins, and red spots. Other clinical signs include a dorsal fin, injury to the injection site, and ulcers (Figure 1.A). Internal symptoms that arise due to $A$. hydrophila infection include the presence of yellow fluid in the abdominal cavity, pale red and tender kidneys, brownish-red liver, heart, gills, pale intestines, swollen stomach filled with water or necrosis of the fins and tail, ulcer (Figure 1.B). Changes in swimming patterns that occur after the fish are infected with A. hydrophila in the form of fish tend to be aggressive with a dorsal fin that is the weakness in the bottom of the aquarium (Figure 1.C). Cloudy skin (indicates excess mucous production due to an irritant bacterial (Figure 1.D) due to bacterial infection of the kidneys. Weakness on the surface of the aquarium (Figure 1.E), as well as a reddish color all over the fish's body (Figure 1.F). Aeromonas bacteria can attack fish fins, tegument, and intestines. According to Rozi et al. (2018), these bacteria are capable of rupturing little blood vessels, resulting in ulcerative lesions in the tegument with a hemorrhagic aspect, causing a reddish color on the body. In this study, besides the ulcerative lesions observed on the body, exophthalmia, and mucus excess were also observed. Rozi et al. (2018) have described these manifestations as clinical signs of $A$. hydrophila infection and, according to Oliveira et al. (2011), the high proliferation of these bacteria on fish intestine can cause excessive mucus liberation. Based on the output test statistics, it was known that the Asymp. Sig. (2-tailed) $<0.05$ for parameters LB, LA, W, U, N, and $\mathrm{H}$. Thus there was a significant difference between the clinical signs of SP and CP. CP clinical symptoms were severe than SP.

Aeromonas hydrophila belongs to the group of pathogenic bacteria with high virulence. The virulence level of the bacteria is determined by the ability of bacteria to produce enzymes and certain toxins it plays a role in the invasion and infection process (Leitão 2020). In the first step, the pathogen attaches to the fish scales and produces the chitinase enzyme. The enzyme destroys the chitin of the scales layer. A further step, the bacteria enter the fish's body through the bloodstream. This process is assisted by the lecithinase enzyme which has a specific function to penetrate the bloodstream. Furthermore, the toxin will spread through the bloodstream (Andriani et al. 2020). The disease caused by A. hydrophila bacteria is called Motile Aeromonad septicemia (MAS) because the infection spreads throughout the body through the bloodstream, infects fish through the surface of the body or wounded gills, and then enters the blood vessels and other internal organs (Ulfiana et al. 2012). According to Yengkhom et al. (2019), disease malignancy is influenced by interrelated factors, such as bacterial virulence, types of bacteria, and the degree of stress affected by fish populations, physiological conditions of the host, and the degree of genetic resistance that cannot be separated in specific populations of fish.

Haryani et al. (2012) also mentioned that the first reaction of animals in cellular and vascular to bacteria that enter the body that causes damage to tissue is inflammation (Table 2). This tissue damage is thought to occur due to toxins released by these bacteria and carried throughout the body through the bloodstream. This was also stated by Andriani et al. (2020), that the toxin was spread throughout the body through the bloodstream causes hemolysis and rupture of blood vessels resulting in redness or red spots on the body of the fish. The appearance of clinical signs can affect the appetite of fish. Fish experience changes in appetite after injection. According to Hardi et al. (2017), fish infected with bacteria take a longer time digesting food than uninfected fish. In infected fish, the feed condition is still intact at $5 \mathrm{~min}$ after giving. This is due to disruption of the digestive enzymes of the fish due to a bacterial infection of the brain that regulates intestinal peristalsis. Bacterial infection of the brain can inhibit the work of the lateral hypothalamus which regulates diet. If the hypothalamus which is in the telencephalon (forebrain) is infected, the fish appetite will decrease (Hardi et al. 2018). Based on Figure 3, gram staining results indicate that $A$. hydrophila bacteria were gram-negative, short rod-shaped, non-spore, motile, and have one flagellum, living in the temperature range $25-30^{\circ} \mathrm{C}$ (Yamazaki et al. 2021). A. hydrophila bacteria are aerobic and facultatively anaerobic. The 16S rRNA primer was used to amplify $356 \mathrm{bp}$. Fragment of the 16S rRNA gene is conserved for the genus Aeromonas to confirm the presence of Aeromonas spp. (Hussain et al. 2013).

Selected gourami that is resistant to disease and has a higher tolerance to environmental disturbances is a key factor to increase the survival in gourami farming. The average mortality in the non-selected control had reached $(63.33 \pm 5.77 \%)$ and was significantly higher $(\mathrm{p}<0.05)$ compared to that of selected gourami $(33.33 \pm 5.77 \%)$. In conclusion, the result of this study demonstrated that non selected group was more susceptible than the selected groups.

\section{ACKNOWLEDGEMENTS}

The DIPA budget funded this study with the Number: SP DIPA-032.12.2.403832 / 2020. We thank Sularto, and laboratory technicians and the gourami team have helped a lot in completing data.

\section{REFERENCES}

Abram QH, Dixon B, Katzenback BA. 2017. Impacts of low temperature on the teleost immune system. Biology 6 (4): 1-15. DOI: 10.3390/biology6040039.

Andriani Y, Handaka AA, Rosidah, Himyati R. 2020. Potential of Telang plant (Clitoria ternatea) for treatment of Aeromonas hydrophila infection on Koi fish (Cyprinus carpio). Revista Agrotec 11 (1): 23 29. DOI: $10.20884 / 1$.oa.2020.16.1.751. 
Aisiah S, Prajitno A, Maftuch M, Yuniarti A. 2020. Effect of Nauclea subdita (Korth.) Steud. leaf extract on hematological and histopathological changes in liver and kidney of striped catfish infected by Aeromonas hydrophila. Vet World 13 (1): 47-53. DOI: 10.14202/vetworld.2020.47-53.

Arifin OZ, Imron I, Muslim N, Hendri A, Aseppendi A, Yani A. 2017. Phenotype and genotype characteristics of gourami, Osphronemus goramy, black Galunggung strain, white Galunggung, and its hybrid. J Aquac Res 12 (2): 99-110. DOI: 10.15578/jra.12.2.2017.99-110. [Indonesian]

Casadevall A. 2017. The pathogenic potential of a microbe. MSphere 2 (1): 1-7. DOI: 10.1128/msphere.00015-17.

Citterio B, Biavasco F. 2015. Aeromonas hydrophila virulence. Virulence 6 (5): 417-418. DOI: 10.1080/21505594.2015.1058479.

Department of Marine Affairs and Fisheries, Padang Pariaman Regency. 2015. Padang Pariaman Minapolitan Master Plan 2015 - 2020 Department of Marine Affairs and Fisheries, Padang Pariaman District, Padang Pariaman. [Indonesian]

Dias MKR, Sampaio LS, Proietti AA, Yoshioka ETO, Rodrigues DP, Rodriguez AFR, Ribeiroe, Faria FSEDV, Ozório ROA, Tavares-Dias M. 2016. Lethal dose and clinical signs of Aeromonas hydrophila in Arapaima gigas (Arapaimidae), the giant fish from Amazon. Vet Microbiol 188: 12-15. DOI: 10.1016/j.vetmic.2016.04.001.

Dove MC, O'Connor WA. 2012. Reproductive cycle of Sydney rock oysters, Saccostrea glomerata (Gould 1850) selectively bred for faster growth. Aquaculture 324-325: 218-225. DOI 10.1016/j.aquaculture.2011.10.022.

Fernández-Bravo A, Figueras MJ. 2020. An update on the genus Aeromonas: Taxonomy, epidemiology, and pathogenicity Microorganisms 8 (1): 129. DOI: 10.3390/microorganisms 8010129.

Gjedrem T, Robinson N, Rye M. 2012. The importance of selective breeding in aquaculture to meet future demands for animal protein: A review. Aquaculture 350-353: 117-129. DOI: 10.1016/j.aquaculture.2012.04.008

Gjedrem T. 2015. Disease resistant fish and shellfish are within reach: A review. J Mar Sci Eng 3: 146-153. DOI: 10.3390/jmse3010146.

GPS (Global Positioning Systems) Coordinate. 2017. Google Play Store.www.google.com/gps. Accessed January 2020.

Hardi EH, Kusuma IW, Suwinarti W, Saptiani G, Sumoharjo S, Lusiastuti AM. 2017. Utilization of several herbal plant extracts on Nile tilapia in preventing Aeromonas hydrophila and Pseudomonas sp. bacterial infection. Nusantara Biosci 9 (2): 220-228. DOI: 10.13057/nusbiosci/n090219.

Hardi EH, Nugroho RA, Saptiani G, Sarinah RIA, Agriandini M, Mawardi, M. 2018. Identification of potentially pathogenic bacteria from tilapia (Oreochromis niloticus) and channel catfish (Clarias batrachus) culture in Samarinda, East Kalimantan Indonesia. Biodiversitas 19 (2): 480-488. DOI: 10.13057/biodiv/d190215.

Haryani A, Roffi G, Ibnu DB, Ayi S. 2012. Effectiveness test of Papaya leaves (Carica papaya) for treatment of Aeromonas hydrophila bacterial infection in Chef carp (Carassius auratus). J Fish Mar Affairs 3 (3): 213-220

Hendry AP, Kinnison MT, Heino M, Day T, Smith TB, Fitt G, et al. 2011 Evolutionary principles and their practical application. Evol Appl 4 (2): 159-183. DOI: 10.1111/j.1752-4571.201000165x.

Hua K, Cobcroft JM, Cole A, Condon K, Jerry DR, Mangott A, Strugnel J. M. 2019. Review the future of aquatic protein: Implications for protein sources in aquaculture diets. One Earth 1 (3): 316-329. DOI: 10.1016/j.oneear.2019.10.018.

Huang YC, Yin Z, Weng S, He J, Li S. 2012. Selective breeding and preliminary commercial performance of Penaeus vannamei for resistance to white spot syndrome virus (WSSV). Aquaculture $364-$ 365: 111-117. DOI: 10.1016/j.aquaculture.2012.08.002.

Hussain IA, Jeyasekaran G, Shakila RJ, Raj KT, Jeevithan E. 2013. Detection of hemolytic strains of Aeromonas hydrophila and $A$ sobria along with other Aeromonas spp. from fish and fishery products by multiplex PCR. J Food Sci Technol 51 (2): 401-407. DOI: $10.1007 / \mathrm{s} 13197-013-1190-9$.

Khasani I, Lusiastuti AM, Zairin M, Alimuddin A. 2017. Resistance to vibriosis, production performance and tolerance to stress of the selected giant freshwater prawn (Macrobrachium rosenbergii). Aquac Res 49 (1): 273-281. DOI: 10.1111/are.13458.

Krishna G, Gopikrishna G, Gopal C, Jahageerdar S, Ravichandran P, Kannappan S, Hayes B. 2011. Genetic parameters for growth and survival in Penaeus monodon cultured in India. Aquaculture 318: 74 78. DOI: 10.1016/j.aquaculture.2011.04.028.
Khumaidi A, Hidayat A. 2018. Identification of causes of mass death of Gurami fish (Osphronemus gouramy) in Gurami Fish Cultivation Sentra, Desa Beji, Kedung Banteng District, Banyumas District, Central Java. J Aqua Sci 3 (2): 145-153. DOI: 10.31093/joas.v3i2.53.

Kusdarwanti R, Kismiyati, Sudarno, Kurniawan H, Prayogi YT. 2017. Isolation and identification of Aeromonas hydrophila and Saprolegnia sp. on Catfish ( Clarias gariepinus ) in Floating cages in Bozem Moro Krembangan Surabaya. IOP Conf Ser Earth Environ Sci 55 (1): 012038. DOI: 10.1088/1755-1315/55/1/012038.

Kusdarwati R, Rozi D, Dinda N, Nurjanah I. 2018. Antimicrobial resistance prevalence of Aeromonas hydrophila isolates from motile Aeromonas septicemia disease. IOP Conf Ser Earth Environ Sci 137 (1): 012076. DOI: 10.1088/1755-1315/137/1/012076.

Kusumawaty D, Pancoro A, Suhandono S. 2016. Evaluation of identification techniques for the fish pathogen, Aeromonas hydrophila, from Indonesia. Malays J Microbiol 12 (3): 191-198. DOI: $10.21161 / \mathrm{mjm} .77915$.

Leitão JH. 2020. Microbial virulence factors. Intl J Mol Sci 21 (15): 1-6. DOI: $10.3390 /$ ijms 21155320 .

Li T, Li H, Gatesoupe FJ, She R, Lin Q, Yan X, Li J, Li X. 2017. Bacterial signatures of "Red-Operculum" disease in the gut of Crucian carp (Carassius auratus). Microbiol Aquat Sys 74: 510-521. DOI: 10.1007/s00248-017-0967-1.

Lionel D, Max N, Elise M. 2015. Mass selection for survival and resistance to OsHV-1 infection in Crassostrea gigas spat in field conditions: Response to selection after four generations. Aquaculture 446: 111-121. DOI: 10.1016/j.aquaculture.2015.04rr.029.

Ma J, Bruce TJ, Jones EM, Cain KD. 2019. A review of fish vaccine development strategies: Conventional methods and modern biotechnological approaches. Microorganisms 7 (11): 569. DOI: 10.3390/microorganisms7110569.

Mangunwardoyo W, Ismayasari R, Riani E. 2016. Pathogenicity and virulence test of Aeromonas hydrophila Stanier on Tilapia (Oreochromis niloticus Lin.) through postulate koch. J Aquac Res 5 (2): 145-255. DOI: 10.15578/jra.5.2.2010.145-255

Marine and Fisheries Ministry. 2018. Gourami cultivation, activator regional economy and improve welfare. [Online] Available at http:// www.djpb. kkp.go.id [accessed October 25, 2019].

Makrinos DL, Bowden TJ. 2016. Natural environmental impacts on teleost immune function. Fish Shellfish Immunol 53: 50-57. DOI: 10.1016/j.fsi.2016.03.008.

Maryadi H. 2011. Study of the Development of Clinical Symptoms and Pathology in Tiger Grouper (Epinephelus fuscoguttatus) Infected with Streptococcus iniae. [Thesis]. Bogor Agricultural University, Bogor. [Indonesian]

Moss SM, Moss DR, Arce SM, Lightner DV, Lotz JM. 2012. The role of selective breeding and biosecurity in the prevention of disease in penaeid shrimp aquaculture. J Invertebr Pathol 110: 247-250. DOI: 10.1016/j.jip.2012.01.013.

Nugroho E, Nafiqoh N, Gustiano R. 2012. Productivity of several varieties of gourami (Osphronemus gourami). Proceedings of the Aquaculture Technology Innovation Forum 2012: 1095-1101.

Olga. 2014. Pathogenicity of Aeromonas hydrophila ASB01 bacteria in snakehead fish (Ophicephalus striatus) (The Pathogenicity of Aeromonas hydrophila ASB01 on snakehead (Ophicephalus striatus) Aquat Sci 14 (1): 33-39.

Oliveira SRD, Souza RTYBD, Brasil EM, Andrade JIAD, Nunes EDSS, OnoEA, Affonso EG. 2011. LD5o of the bacteria Aeromonas hydrophila to matrinxã, Brycon amazonicus. Acta Amazon 41 (2): 321-326. DOI: 10.1590/s0044-59672011000200019.

Öztürk RÇ, Altinok I. 2014. Bacterial and viral fish diseases in Turkey. Turkish J Fish Aquat Sci 14 (1): 275-297. DOI: 10.4194/1303-2712v14_1_30.

Parker LM, Ross PM, O’Connor WA. 2011. Populations of the Sydney rock oyster, Saccostrea glomerata, vary in response to ocean acidification. Mar Biol 158 (3): 689-697. DOI: 10.1007/s00227-0101592-4.

Purwaningsih U, Indrawati A, Lusiastuti AM. 2014. Protection of monovalent vaccines and whole cocktails against co-infection of Mycobacterium fortuitum and Aeromonas hydrophila in gourami, Osphronemus gourami. J Aquac Res 9 (2): 283-294. DOI: 10.15578/jra.9.2.2014.283-294.

Rao K, Benarjee PG. 2016. Haematological changes in South Indian freshwater murrel, Channa punctatus have both EUS and $A$. hydrophila infection. J Parasit Dis 41 (2): 329-335 DOI: 10.1007/s12639-016-0798-x. 
Republic of Indonesia. 2017. Government Regulation No. 32 concerning Fish Farming, President of the Republic of Indonesia. Minister of the Environment, Jakarta. [Indonesian]

Reid GK, Gurney-Smith HJ, Marcogliese DJ, Chopin T, Brewer-Dalton K, Moccia RD, Flaherty M. 2019. Climate change and aquaculture : Considering biological response and resources. Aquac Environ Interact 11: 569-602. DOI: 10.3354/aei00332.

Rozi R, Rahayu K, Daruti DN, Stella MSP. 2018. Study on characterization, pathogenicity and histopathology of disease caused by Aeromonas hydrophila in gourami (Osphronemus gourami). IOP Conf Ser Earth Environ Sci 137: 012003. DOI: 10.1088/17551315/137/1/012003.

Subhan U, Mauladani S, Rosidah, Suryadi IBB, Joni IM. 2020. Promising application of fine bubbles (FBs) to control Aeromonas hydrophila on striped catfish seed (Pangasianodon hypophthalmus). AIP Conf Proceed 2219: 090002. DOI: 10.1063/5.0003059.

Suebsong W, Poompuang S, Srisapoome P, Koonawootrittriron S, Luengnaruemitchai A, Johansen H, Rye M. 2019. Selection response for Streptococcus agalactiae resistance in Nile tilapia Oreochromis niloticus. J Fish Dis 42 (11): 1553-1562. DOI: 10.1111/jfd.13074.

Sularto, Febrianti R, Suharyanto, 2016. Heritability estimation and selection response of Goramy crosses (Osphronemus goramy Lac.). J. Aquac Res 11 (1): 23-28. DOI: 10.15578/jra.11.1.2016.23-28.

Sularto, Febrianti R, Listiyowati R. 2020. Research and Development of Superior Strain Gourami in Society. Fish Breeding Research Institute. Research Activity Technical Report 2020, Sukamandi, Subang.

Suprapto S, Kairudin NM. 2017. Genetic variation, heritability, genetic action and genetic progress of soybean (Glycine max Merrill) on ultisol. Indon J Agric Sci 9 (2): 183-190. DOI: 10.31186/jipi.9.2.183190.

Taukhid, Gardenia L, Andriyanto S. 2016. The efficacy of the "trivalent" combination vaccine (Aeromonas hydrophila, Streptococcus agalactiae, and Mycobacterium fortuitum) for the prevention of potential bacterial diseases in freshwater fish culture. J Aquac Res 11 (4): 373-385. DOI: 10.15578/jra.11.4.2016.373-385.
Trang TT, Hung NH, Ninh NH, Knibb W, Nguyen NH. 2019. Genetic variation in disease resistance against white spot syndrome virus (WSSV) in Liptopenaeus vannamei. Front Genet 10: 1-10. DOI: 10.3389/fgene.2019.00264

Tripathi GS, Tripathi G, Singh P. 2018. Assessment of different water quality parameters under bottle aquaponic system and normal controlled conditions with Trichopodus trichopterus (Blue gourami). J Entomol Zool Stud 6 (6): 898-902.

Ulfiana R, Mahasri G, Suprapto S. 2012. Occurrence rate of Aeromonasis in Koi fish (Cyprinus carpio) infected by Myxobolus koi at different degrees of infection. J Fish Mar Sci 4 (2): 169-174. DOI: 10.20473/jipkv4i2.11568.

Wulandari A, Prayitno SB, Sarjito. 2014. Pathogenicity of K14 isolate isolated from African catfish (Clarias gariepinus) originating from Demak. J Aquac Manag Technol 3 (2): 143-149.

Yamazaki K, Kashimoto T, Niwano A, Yamasaki M, Nomura M, Akeda Y, Ueno S. 2021. Expansion of necrosis depending on hybrid motordriven motility of Aeromonas hydrophila in a murine wound infection model. Microorganisms 9 (1): 1-12. DOI: 10.3390/microorganisms9010010.

Yanez JM, Lhorente JP, Bassini LN, Oyarzu NM, Neira R, Newman S. 2014. Genetic covariation between resistance against both Caligus rogercresseyi and Piscirickettsia salmonis, and body weight in Atlantic salmon, Salmo salar. Aquaculture 433: 295-298. DOI: 10.1016/j.aquaculture.2014.06.026.

Yengkhom O, Shalini KS, Subramani PA, Michael RD. 2019 Stimulation of nonspecific immunity, gene expression, and disease resistance in Nile tilapia, Oreochromis niloticus (Linnaeus, 1758), by the methanolic extract of the marine macroalga, Caulerpa scalpelliformis. Vet World 12: 271-276. DOI: 10.14202/vetworld.2019.271-276.

Zubaidah A, Samsundari S, Hidayaturrahmi H. 2019. Effectiveness of strychnine bush extract (Strychnos ligustrina Blume) against to prevalence and survival rate of Dumbo catfish (Clarias gariepinus) infected with Aeromonas hydrophila. Indones J Trop Aquat 2 (1): 1. DOI: 10.22219/ijotav2i1.5601. 